\title{
Larvicidal activity and possible mode of action of four flavonoids and two fatty acids identified in Millettia pinnata seed toward three mosquito species
}

Haribalan Perumalsamy' ${ }^{1}$ Myung Jin Jang ${ }^{2}$, Jun-Ran $\mathrm{Kim}^{3}$, Murugan Kadarkarai ${ }^{4}$ and Young-Joon $\mathrm{Ahn}^{2^{*}}$

\begin{abstract}
Background: Aedes aegypti and Aedes albopictus and Culex pipiens pallens mosquitoes transmit dengue fever and West Nile virus diseases, respectively. This study was conducted to determine the toxicity and mechanism of action of four flavonoids and two fatty acids from Millettia pinnata (Fabaceae) seed as well as six pure fatty acids and four fatty acid esters toward third instar larvae from insecticide-susceptible C. pipiens pallens and A. aegypti as well as wild A. albopictus. Efficacy of 12 experimental liquid formulations containing M. pinnata seed methanol extract and hydrodistillate (0.5-10.0\% liquids) was also assessed.
\end{abstract}

Methods: The contact toxicities of all compounds and 12 formulations were compared with those of two larvicides, temephos and fenthion and the commercial temephos $200 \mathrm{~g} / \mathrm{L}$ emulsifiable concentrate (EC). The possible mode of larvicidal action of the constituents was elucidated using biochemical methods. Larval mortality and CAMP level were analyzed by the Bonferroni multiple-comparison method.

Results: Potent toxicity was produced by karanjin, oleic acid, karanjachromene, linoleic acid, linolenic acid, pongamol, pongarotene, and elaidic acid toward C. pipiens pallens larvae $\left(24 \mathrm{~h} \mathrm{LC} \mathrm{C}_{50}, 14.61-28.22 \mathrm{mg} / \mathrm{L}\right)$ and $A$. aegypti larvae (16.13-37.61 mg/L). Against wild A. albopictus larvae, oleic acid ( $\left.\mathrm{LC}_{50}, 18.79 \mathrm{mg} / \mathrm{L}\right)$ and karanjin (35.26 mg/L) exhibited potent toxicity. All constituents were less toxic than either temephos or fenthion. Structure-activity relationship indicates that the degree of saturation, the side chain length, and the geometric isomerism of fatty acids appear to play a role in determining the fatty acid toxicity. Acetylcholinesterase (AChE) is the main site of action of the flavonoids, oleic acid, and palmitic acid. The mechanism of larvicidal action of elaidic acid, arachidic acid, and behenic acid might be due to interference with the octopaminergic system. Linoleic acid and linolenic acid might act on both AChE and octopaminergic receptor. M. pinnata seed extract or hydrodistillate applied as 10\% liquid provided 100\% mortality toward the three mosquito species larvae and the efficacy of the liquids was comparable to that of temephos $200 \mathrm{~g} / \mathrm{L} \mathrm{EC}$.

Conclusion: Further studies will warrant possible applications of M. pinnata seed-derived products as potential larvicides for the control of mosquito populations.

Keywords: Millettia pinnata, Fabaceae, Seed, Natural mosquito larvicide, Flavonoids, Fatty acids,

Acetylcholinesterase inhibition, Octopaminergic receptor

\footnotetext{
* Correspondence: yjahn@snu.ac.kr

${ }^{2}$ Department of Agricultural Biotechnology, Seoul National University, Seoul

151-921, Republic of Korea

Full list of author information is available at the end of the article
}

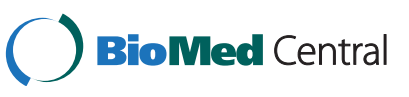

(c) 2015 Perumalsamy et al.; licensee BioMed Central. . This is an Open Access article distributed under the terms of the Creative Commons Attribution License (http://creativecommons.org/licenses/by/4.0), which permits unrestricted use, distribution, and reproduction in any medium, provided the original work is properly credited. The Creative Commons Public Domain Dedication waiver (http://creativecommons.org/publicdomain/zero/1.0/) applies to the data made available in this article, unless otherwise stated. 


\section{Background}

The yellow fever mosquito, Aedes aegypti (Linnaeus 1762) [1], the Asian tiger mosquito, Aedes albopictus (Skuse 1894) [2], and the northern house mosquito, Culex pipiens pallens (Coquillett 1898) [3], are serious disease vectoring insect pests because of their widespread distribution and abundance worldwide [4]. More than 2.5 billion people are at risk of dengue infection over 100 countries worldwide, and there may be $50-100$ million dengue infections every year, including 22000 deaths annually, mostly among children [5]. A recent study calculated that 3.97 billion people are at risk of dengue infection in 128 countries worldwide [6,7]. From 1999 to 2010, 37088 cases of human West Nile virus disease (including 16196 neuroinvasive disease cases) were reported in the United States (US), resulting in 1549 deaths [8]. With global warming, increased international travel, and tainted fresh water pools, a number of mosquitoes are distinctly increasing in incidence with a high occurrence of dengue fever all over the globe $[9,10]$. Widespread insecticide resistance [11] has been a major obstacle in the cost-effective integrated mosquito management program. In addition, the number of approved insecticides may be reduced in the near future in the US [12] and in the European Union [13] because of reregistration of conventional insecticides. The removal of conventional insecticide products from markets due to the increase in insecticide resistance or other concerns will have a serious impact on the proliferation of mosquitoes. There is a pressing need for the development of selective alternatives for the control of mosquitoes, with novel target sites to establish a rational management strategy and tactics because vaccines for malaria [14] or dengue [15] are not yet available.

Plants have been suggested as alternative sources for conventional mosquito larvicides largely because they constitute a potential source of bioactive secondary substances that have been perceived by the general public as relatively safe and with less risk to the environment, and with minimal impacts to animal and human health [16-18]. Secondary substances often act at multiple and novel target sites [18-20], thereby reducing the potential for resistance $[21,22]$. They are regarded as potential sources for developing commercial insecticides as certain plant preparations and their constituents meet the criteria as minimum-risk insecticides [23]. Previous studies have shown that a methanol extract from the seeds of Indian beech, Millettia pinnata (L.) Panigrahi (Fabaceae) (formerly Pongamia pinnata (L.) Pierre), possessed good larvicidal activity toward $C$. pipiens pallens and $A$. aegypti. No information is available concerning the potential use of $M$. pinnata seed-derived materials for managing mosquitoes for future commercialization, although phytochemistry, pharmacological activities, and traditional and folk medicine uses of the plant have been well documented by Arote and Yeole [24] and Meera et al. [25].

The aim of the study was to assess the contact toxicity of the four flavonoids (karanjin, karanjachromene, pongamol, and pongarotene) and two fatty acids (oleic acid and palmitic acid) from $M$. pinnata seed extract and the five organic pure fatty acids from the seed hydrodistillate and one structurally related compound (elaidic acid), as well as two fatty acid methyl esters and two fatty acid ethyl esters to third instar larvae from insecticidesusceptible $C$. pipiens pallens and $A$. aegypti, as well as a wild colony of $A$. albopictus. Results were compared with those of the two conventional larvicides temephos and fenthion. The efficacy of 12 liquid formulations $(0.5-10 \%)$ containing the seed extract or hydrodistillate were compared with those of the commercial larvicide temephos $200 \mathrm{~g} / \mathrm{L}$ emulsifiable concentrate (EC) because the larvicide is known to have low toxicity to mammals and aquatic organisms and is less persistent in the environment [26]. Quantitative structure-activity relationship (QSAR) of the test compounds is also discussed. In addition, the possible mode of larvicidal action of the constituents was elucidated using biochemical methods.

\section{Methods}

\section{Instrumental analysis}

${ }^{1} \mathrm{H}$ and ${ }^{13} \mathrm{C}$ NMR spectra were recorded in $\mathrm{CDCl}_{3}$ on an AVANCE 600 spectrometer (Bruker, Rheinstetten, Germany) at 400 and $100 \mathrm{MHz}$, respectively, using tetramethylsilane as an internal standard, and chemical shifts are given in $\delta$ (ppm). Distortionless enhancement by polarization transfer spectra was acquired using the Bruker software. UV spectra were obtained in methanol or acetone on a UVICON 933/934 spectrophotometer (Kontron, Milan, Italy), and mass spectra on a JMS-DX 303 spectrometer (Jeol, Tokyo, Japan). Silica gel 60 (0.063-0.2 mm) (Merck, Darmstadt, Germany) was used for column chromatography. Merck precoated silica gel plates (Kieselgel $60 \mathrm{~F}_{254}$ ) were used for analytical thin-layer chromatography (TLC). An Agilent 1200 series high-performance liquid chromatography (HPLC) (Agilent, Santa Clara, CA) was used for isolation of active principles.

\section{Materials}

Eight fatty acids and four fatty acid esters used in this study were as follows: palmitic acid (C16:0), stearic acid (C18:0), oleic acid (C18:1n9), linoleic acid (C18:2n6), linolenic acid (C18:3n3), methyl oleate, ethyl oleate, methyl linoleate, and ethyl linoleate purchased from Sigma-Aldrich (St. Louis, MO); arachidic acid (C20:0), behenic acid (C22:0), and elaidic acid (C18:1n9) purchased from Tokyo Chemical Industry (Tokyo). The organophosphorus (OP) 
insecticides temephos (97.3\% purity) and fenthion (98.4\% purity) were purchased from Riedel (Seelze, Germany) and Supelco (West Chester, PA), respectively. Commercial temephos $200 \mathrm{~g} / \mathrm{L}$ EC was supplied by Pharmcle (Seoul, Republic of Korea (ROK)). Ethoxylated castor oil + polyoxyethylene dodecyl mono ether, a surfactant, was a gift from Hannong Chemical (Anyang, Gyeonggi, ROK). Acetylthiocholine iodide (ATChI), 5, 5'-dithio-bis(2nitrobenzoate) (DTNB), eserine salicylate, and octopamine were purchased from Sigma-Aldrich. Bovine serum albumin (BSA) and cyclic AMP (cAMP) Biotrak Enzyme immunoassay system were purchased from Sigma-Aldrich and GE Healthcare (Little Chalfont, Buckinghamshire, UK), respectively. Mouse monoclonal antibody and horseradish peroxidase-labeled cAMP were purchased from R\&D Systems (Minneapolis, MN). All of the other chemicals and reagents used in this study were of analytical grade quality and available commercially.

\section{Mosquitoes}

The stock cultures of $C$. pipiens pallens and A. aegypti [27] have been maintained in the laboratory without exposure to any known insecticide. Engorged $A$. albopictus females were collected near rice paddy fields and cowsheds in Daejeon (ROK) in early August, 2011 using black light FL-6w traps (Shinyoung, Seoul). The rice paddy fields and cow sheds had varying histories of insecticide use. They have been separately maintained in temperature-controlled insect rearing rooms (Seoul National University) to prevent cross-contamination. Larvae were reared in plastic trays $(24 \times 35 \times 5 \mathrm{~cm})$ containing $0.5 \mathrm{~g}$ of sterilized diet (40-mesh chick chow powder/yeast, $1 / 1$ by weight). Adults were maintained on a $10 \%$ sucrose solution and blood fed on live mice. All stages were held at $27 \pm 1^{\circ} \mathrm{C}$ and $65-75 \%$ relative humidity under a 16:8 h light:dark cycle. The wild mosquitoes were reared for four generations to ensure sufficient numbers for testing.

\section{Plant material}

Seeds of $M$. pinnata were collected from the foothill at Western Ghats $\left(11^{\circ} 22^{\prime} 30^{\prime}\right.$ 'N , 76 45'30' 'E) (Coimbatore, Tamil Nadu, India) in September 2009. A certified botanical taxonomist was used to identify the plant. A voucher specimen (MP-01) was deposited in the Research Institute of Agriculture and Life Sciences, Seoul National University.

\section{Hydrodistillation}

Seeds (500 g) of M. pinnata were pulverized and subjected to hydrodistillation at $100^{\circ} \mathrm{C}$ for $2 \mathrm{~h}$ using a Clevenger-type apparatus. The volatile oil was dried over anhydrous sodium sulfate and stored in a sealed vial at $4^{\circ} \mathrm{C}$ until use. The yield of the hydrodistillate from the seeds was $1.87 \%$. The seed hydrodistillate was used for fatty acid analysis and experimental formulations.

\section{Experimental liquid formulations}

Twelve experimental liquid formulations containing $M$. pinnata seed methanol extract (MPS-ME) and seed hydrodistillate (MPS-HD) were prepared to determine the effective larvicide products. The $0.5,1,2.5,5,7.5$, and $10 \%$ liquid formulations were, respectively, composed of $0.5,1,2.5,5,7.5$, and $10 \%$ of the corresponding extract or hydrodistillate, 2\% surfactant (ethoxylated castor oil + polyoxyethylene dodecyl mono ether), 5\% ethanol, and sterile distilled water at 92.5, 92, 90.5, 88, 85.5 , and $83 \%$.

\section{Extraction and isolation}

Air-dried seeds (260 g) of M. pinnata were pulverized, extracted with methanol $(2 \times 6 \mathrm{~L})$ at room temperature for 1 day, and filtered. The combined filtrate was concentrated to dryness by rotary evaporation at $40^{\circ} \mathrm{C}$ to yield $\sim 46.42 \mathrm{~g}$ of a pale yellowish tar. The extract $(40 \mathrm{~g})$ was sequentially partitioned into hexane- $(6.44 \mathrm{~g})$, chloroform- $(5.92 \mathrm{~g})$, ethyl acetate- $(1.0 \mathrm{~g})$, butanol$(2.06 \mathrm{~g})$, and water-soluble (24.58 g) portions for subsequent bioassay. The organic solvent-soluble portions were concentrated under vacuum at $40^{\circ} \mathrm{C}$, and the water-soluble portion was freeze-dried. For isolation of active principles, $50 \mathrm{mg} / \mathrm{L}$ of each $M$. pinnata seedderived material was tested in a direct-contact mortality bioassay, as described previously [28].

The chloroform-soluble fraction $(2.96 \mathrm{~g}$ ) was most biologically active (Table 1 ) and was recrystallized in methanol at $-4^{\circ} \mathrm{C}$ to afford compound 1 (46 mg) (Figure 1A). The remaining portion (2.91 g) was chromatographed on a $70 \times 5.5 \mathrm{~cm}$ silica gel $(300 \mathrm{~g})$ column by elution with a gradient of chloroform and methanol [(100:0 (1 L), 99:1 (2 L), 98:2 (2 L), 95:5 (2 L), 90:10 (2 L), 70:30 $(1 \mathrm{~L})$, and 0:100 (1 L) by volume] to provide 28 fractions (each about $250 \mathrm{~mL}$ ). Column fractions were monitored by TLC on silica gel plates developed with chloroform and methanol (98:2 by volume) mobile phase. Column fractions with similar $R_{\mathrm{f}}$ values on the TLC plates were pooled. Spots were detected by spraying with $2 \% \mathrm{H}_{2} \mathrm{SO}_{4}$ and then heating on a hot plate. Active fractions 7 to 11 (40 mg) were pooled and purified by preparative TLC plates developed with chloroform and methanol (98:2 by volume) to provide compound 2 ( $\left.3 \mathrm{mg}, R_{\mathrm{f}}=0.61\right)$. The other active hexane-soluble fraction ( $5 \mathrm{~g}$ ) was chromatographed on a $70 \times 5.5 \mathrm{~cm}$ silica gel $(300 \mathrm{~g})$ column by elution with a gradient of hexane and ethyl acetate [(10:1 (2.2 L), 9:1 (2 L), 7:3 (2 L), 5:5 (1 L), and 3:7 (1 L) by volume] and finally with methanol $(1 \mathrm{~L})$ to provide 48 fractions (each about $250 \mathrm{~mL}$ ) (Figure 1B). Column fractions were monitored by TLC on silica gel plates 
Table 1 Toxicity of each fraction obtained from the solvent partitionings of the methanol extract of Millettia pinnata seeds and seed hydrodistillate to third instar larvae from insecticide-susceptible Culex pipiens pallens and Aedes aegypti and wild Aedes albopictus during a $24 \mathrm{~h}$ exposure

\begin{tabular}{llll}
\hline Material & \multicolumn{1}{l}{ LC $\mathbf{5 0}, \mathbf{~ m g} / \mathbf{L}(\mathbf{9 5 \%} \mathbf{C L})$} & A. albopictus \\
\cline { 2 - 4 } & C. pipiens pallens & A. aegypti & $61.30(54.75-69.79)$ \\
\hline Methanol extract & $24.19(20.67-28.59)$ & $27.70(24.53-31.82)$ & $54.70(50.57-60.10)$ \\
Hexane-soluble fr. & $19.81(17.35-22.66)$ & $22.21(19.34-25.08)$ & $43.83(40.01-48.40)$ \\
Chloroform-soluble fr. & $12.40(10.39-14.96)$ & $14.51(12.41-16.77)$ & $77.21(73.36-82.28)$ \\
Ethyl acetate-soluble fr. & $73.27(69.24-78.23)$ & $75.29(71.27-80.50)$ & $134.58(126.14-146.18)$ \\
Butanol-soluble fr. & $95.95(92.07-100.91)$ & $97.60(93.54-103.04)$ & $>200$ \\
Water-soluble fr. & $>200$ & $>200$ & $47.99(39.10-60.79)$ \\
Hydrodistillate & $27.38(22.83-32.46)$ & $32.57(27.20-38.80)$ &
\end{tabular}

developed with hexane and ethyl acetate (7:3 by volume) mobile phase. Fractions with similar $R_{\mathrm{f}}$ values on the TLC plates were pooled, as stated previously. Three active fractions 4 to $8(\mathrm{H} 2,1.24 \mathrm{~g}), 9$ to $12(\mathrm{H} 3,590 \mathrm{mg})$, and 16 to $22(\mathrm{H} 5,1.02 \mathrm{~g})$ were obtained. Fraction $\mathrm{H} 2$ was recrystallized in hexane at $-4^{\circ} \mathrm{C}$ to afford compound 3 (78 mg). Fraction H3 was purified by preparative TLC plates developed with hexane and ethyl acetate $(7: 3$ by volume $)$ to yield compound $4\left(85 \mathrm{mg}, R_{\mathrm{f}}=0.61\right)$.
Fraction H5 was rechromatographed on a $70 \times 5.5 \mathrm{~cm}$ silica gel $(300 \mathrm{~g})$ column by elution with a gradient of hexane and ethyl acetate [(10:1 (2.2 L), 9:1 (2 L), 7:3 (2 L), 5:5 (1 L), and 3:7 (1 L) by volume] and finally with methanol ( $1 \mathrm{~L})$ to provide 25 fractions (each about $150 \mathrm{~mL}$ ). A preparative HPLC was used for separation of the constituents from the active fractions 9 to 14 (H52, $45 \mathrm{mg}$ ) and 18 to 22 (H54, $75 \mathrm{mg}$ ). The column was a $7.8 \mathrm{~mm}$ i.d. $\times 300 \mathrm{~mm}$ Waters $\mu$ Bondapak C18 (Milford,

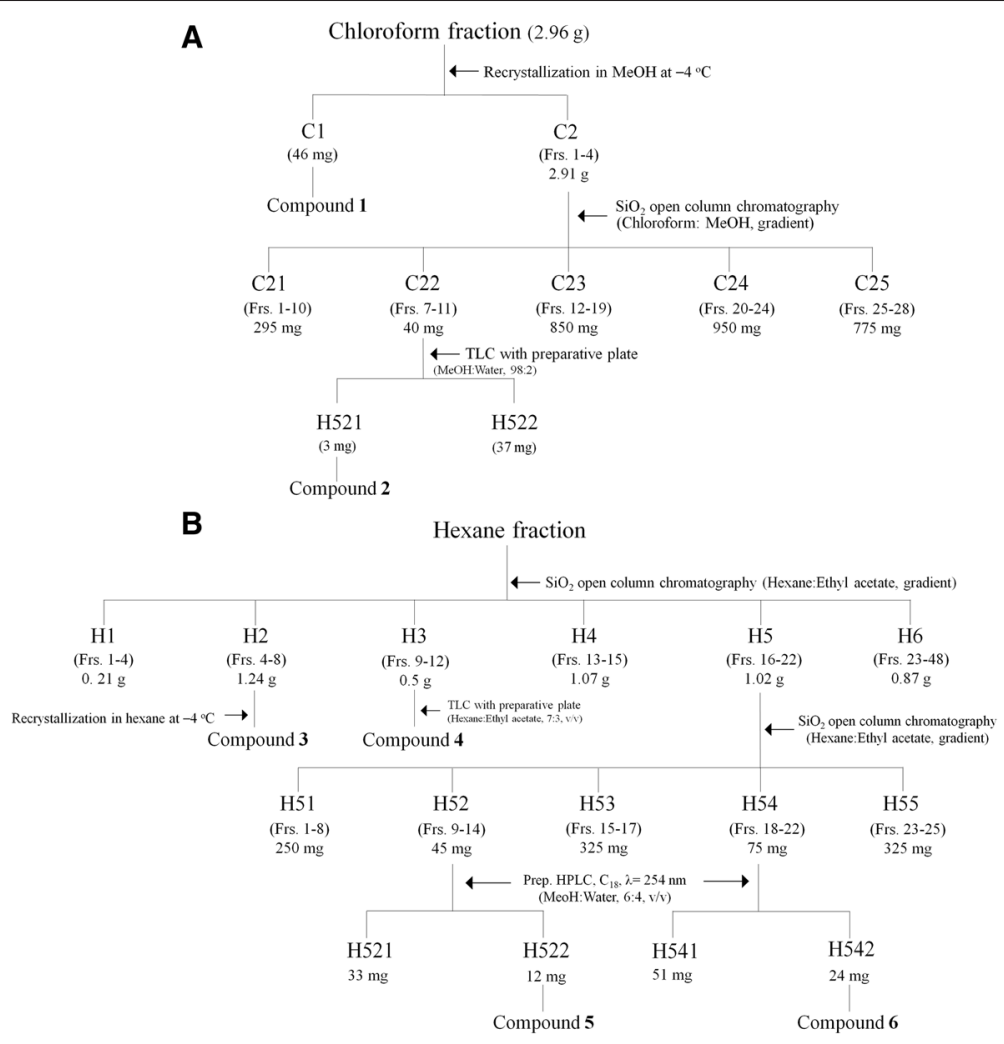

Figure 1 Isolation procedures of larvicidal principles. The Millettia pinnata seed methanol extract was sequentially partitioned into hexane-, chloroform-, ethyl acetate-, butanol-, and water-soluble portions. For isolation of active principles from the chloroform-soluble fraction (A) and hexane-soluble fraction (B), $50 \mathrm{mg} / \mathrm{L}$ of each M. pinnata seed-derived material was tested in a direct-contact mortality bioassay toward third instar larvae from Culex pipiens pallens and Aedes aegypti. 
MA) with a mobile phase of methanol and water (6:4 by volume) at a flow rate of $1 \mathrm{~mL} / \mathrm{min}$. Chromatographic separations were monitored using a UV detector at $254 \mathrm{~nm}$. Finally, two active principles $5(12 \mathrm{mg})$ from fraction $\mathrm{H} 52$ and 6 (24 mg) from fraction $\mathrm{H} 54$ were isolated at a retention time of 19.30 and $31.22 \mathrm{~min}$, respectively.

Fatty acid analysis of Millettia pinnata seed hydrodistillate Because MPS-HD contains various free fatty acids with low volatility [29,30], fatty acid methyl esters (FAMEs) were prepared following the method described previously by Rafael and Mancha [31]. In brief, $1 \mu \mathrm{g}$ of MPSHD was methylated overnight at $25^{\circ} \mathrm{C}$ with diazomethane in $200 \mu \mathrm{L}$ of diethyl ether. Solvent and excess diazomethane were removed under a stream of $\mathrm{N}_{2}$, and the residue was redissolved in diethyl ether for gas chromatography (GC) analysis.

GC of the FAMEs was performed using an Agilent 7890A gas chromatograph (Agilent, Palo Alto, CA) equipped with a split injector and a flame ionization detection (FID) system. Constituents were separated with a $30 \mathrm{~m} \times 0.25 \mathrm{~mm}$ i.d. $\left(d_{\mathrm{f}}=0.25 \mu \mathrm{m}\right)$ DB-wax capillary column (Agilent J\&W Scientific, Folsom, CA). The oven temperature was kept at $50^{\circ} \mathrm{C}(1 \mathrm{~min}$ isothermal $)$ and programmed to $200^{\circ} \mathrm{C}$ at a rate of $25^{\circ} \mathrm{C} / \mathrm{min}$, and then $230^{\circ} \mathrm{C}$ at a rate of $3^{\circ} \mathrm{C} / \mathrm{min}$ (held for $6 \mathrm{~min}$ at final temperature). The linear velocity of the nitrogen carrier gas was $36 \mathrm{~cm} / \mathrm{s}\left(\right.$ at $50^{\circ} \mathrm{C}$ ) at a split ratio of $50: 1$. The constituents were identified by coelution of authenticated samples following coinjection, and their composition was calculated to percentage content based on peak area.

\section{Gas chromatography-mass spectrometry of methylated samples}

The gas chromatography-mass spectrometry (GC-MS) analysis of methylated samples was performed using a HP 6890 gas chromatograph-JMS-600 W mass spectrometer for further identification of fatty acids on the GC-FID chromatogram. The capillary column and temperature conditions for the GC-MS analysis were the same as those stated previously for GC analysis. Helium carrier gas was used at a column head pressure of 15.7 psi $(39.2$ $\mathrm{kPa})$. The ion source temperature was $230^{\circ} \mathrm{C}$, and mass spectra were obtained in EI-scan mode at $70 \mathrm{eV}$ electron energy.

\section{Bioassay}

A direct-contact mortality bioassay [28] was used to evaluate the toxicity of all compounds to third instar larvae from the susceptible and wild mosquito populations. Each compound in acetone (for karanjin) or methanol (for the other compounds) was suspended in distilled water with Triton X-100 $(20 \mu \mathrm{L} / \mathrm{L})$. Groups of 20 mosquito larvae were separately put into paper cups $(270 \mathrm{~mL})$ containing each test compound solution $(250 \mathrm{~mL})$. The OPs temephos and fenthion served as positive controls and were similarly formulated. Negative controls consisted of the acetone- or methanol-Triton X-100 solution in distilled water. Based on the preliminary test results, the toxicity of each compound and insecticide was determined with four to six concentrations ranging from 0.1 to $200 \mathrm{mg} / \mathrm{L}$ and 0.001 to $0.1 \mathrm{mg} / \mathrm{L}$, respectively. Treated and control (acetone- or methanol-Triton X100 solution only) larvae were held under the same conditions as those used for colony maintenance. At $24 \mathrm{~h}$ post-treatment, a larva was considered dead if it did not move when prodded with a fine wooden dowel [28]. All treatments were replicated three times using 20 larvae per replicate.

In separate experiments, the efficacy of the 12 experimental liquid formulations was evaluated, as stated previously. Groups of 20 mosquito larvae were separately put into paper cups containing each test solution. Temephos $200 \mathrm{~g} / \mathrm{L}$ EC served as a positive control. Negative controls consisted of the ethoxylated castor oil + polyoxyethylene dodecyl mono ether solution in distilled water or water. Mortalities were recorded, as stated previously. All treatments were replicated three times using 20 larvae per replicate.

\section{Acetylcholinesterase assay}

Third instar larvae of $A$. aegypti was used in all experiments. Whole bodies of the larvae $(14.5 \mathrm{mg}$ fresh weight/1 mL buffer) were homogenized in $2 \mathrm{~mL}$ of icecold $0.1 \mathrm{M}$ phosphate buffer ( $\mathrm{pH}$ 8.0) using a Teflon glass tissue homogenizer. After filtering through cheese cloth, the homogenate was centrifuged at $1000 \mathrm{~g}$ at $4^{\circ} \mathrm{C}$ for $5 \mathrm{~min}$. The supernatant was used as the acetylcholinesterase (AChE) preparation. Protein content was determined by the Bradford dye method [32] using BSA as the standard. Microplate AChE assay was carried out following the method of Hemingway et al. [33] adapted from Ellman et al. [34]. The reaction mixture consisted of $50 \mu \mathrm{L}$ of the crude enzyme preparation, $150 \mu \mathrm{L}$ of $0.1 \mathrm{M}$ phosphate buffer, $20 \mu \mathrm{L}$ of $3 \mathrm{mM}$ DTNB in phosphate buffer ( $\mathrm{pH} 7.0$ ), and $1 \mu \mathrm{L}$ of various concentrations of each test compound in ethanol. The reaction mixture was incubated at $30^{\circ} \mathrm{C}$ for $5 \mathrm{~min}$ and $20 \mu \mathrm{L}$ of $32 \mathrm{mM}$ ATChI was then added to the mixture. After incubation for $30 \mathrm{~min}$, the reaction was stopped by adding $20 \mu \mathrm{L}$ of $5 \mathrm{mM}$ eserine salicylate. The absorbance was recorded at $412 \mathrm{~nm}$ using a VersaMax microplate reader (Molecular Devices, Sunnyvale, CA). Results were expressed as mean $\pm \mathrm{SE}$ of triplicate samples of three independent experiments. 


\section{Determination of cyclic AMP level}

The in vitro octopamine sensitive adenylate cyclase activity was investigated according to the modified method of Pratt and Pryor [35]. The whole bodies of 75 third instar A. aegypti larvae (106.2 $\mathrm{mg}$ ) were homogenized in $500 \mu \mathrm{L}$ of $2 \mathrm{mM}$ Tris-maleate buffer (pH 7.4) containing $0.8 \mathrm{mM}$ ethylene glycol tetraacetic acid (EGTA). Adenylate cyclase activity was measured using a cAMP Biotrak Enzyme immunoassay system according to the manufacturer's instructions. The assay was conducted in a total volume of $100 \mu \mathrm{L}$ containing $80 \mathrm{mM}$ Tris-maleate buffer, $5 \mathrm{mM}$ theophylline (to inhibit phosphodiesterase activity), $2 \mathrm{mM} \mathrm{MgSO}_{4}, 0.5 \mathrm{mM}$ adenosine triphosphate (ATP), $0.2 \mathrm{mM}$ EGTA, $50 \mu \mathrm{L}$ of whole body homogenate (equivalent to $4.22 \mu \mathrm{g}$ protein), and $1 \mu \mathrm{L}$ of the test compounds in Tris-maleate buffer containing $0.2 \%$ ethanol. After incubation for $5 \mathrm{~min}$ at $20^{\circ} \mathrm{C}$, the reaction was initiated by the addition of ATP. Incubation was carried out at $30^{\circ} \mathrm{C}$ for $3 \mathrm{~min}$ in a shaking water bath. The reaction was terminated by boiling for $2 \mathrm{~min}$, and then the assay tube was cooled and centrifuged for $10 \mathrm{~min}$ at $8000 \mathrm{~g}$. The $50 \mu \mathrm{L}$ aliquots of the supernatant were assayed for cAMP level.

The polystyrene microplates ( 1 strip of 8 wells) coated with a goat anti-mouse polyclonal antibody were used. Fifty microliters of primary antibody (mouse monoclonal antibody) solution was added to each well except the blank wells (or the nonspecific binding (NSB) wells). The wells covered with the adhesive strip were incubated for $1 \mathrm{~h}$ at $25^{\circ} \mathrm{C}$ in a shaking incubator $(480 \mathrm{rpm})$, followed by four times washing steps, each with $400 \mu \mathrm{L}$ of wash buffer. The $50 \mu \mathrm{L}$ of the test samples for cAMP determination and cAMP standard were added to wells. Control, blank (NSB), and zero standard wells were added with $50 \mu \mathrm{L}$ of the diluent RD5-55 buffer. The $50 \mu \mathrm{L}$ of cAMP conjugate (horseradish peroxidase-labeled cAMP) was then added to wells. The plate covered with a new adhesive strip was incubated for $2 \mathrm{~h}$ at $25^{\circ} \mathrm{C}$ on the shaker, followed by the four times washing steps. Then, $200 \mu \mathrm{L}$ of substrate solution (equal volume of stabilized hydrogen peroxide and stabilized chromogen) was added to each well, and the test plate was incubated for $30 \mathrm{~min}$ at $25^{\circ} \mathrm{C}$ on the benchtop in darkness. Finally, the reaction was stopped by adding $100 \mu \mathrm{L}$ of stop solution ( $2 \mathrm{~N}$ sulfuric acid) to each well. Optical densities at 450 and $540 \mathrm{~nm}$ were measured using the VersaMax microplate reader. The readings at $540 \mathrm{~nm}$ were subtracted from the readings at $450 \mathrm{~nm}$. The cAMP concentrations were expressed as $\mathrm{nmol} / \mu \mathrm{g}$ protein. $\mathrm{Re}$ sults were expressed as mean $\pm \mathrm{SE}$ of duplicate samples of three independent experiments.

\section{Data analysis}

Data were corrected for control mortality using Abbott's formula [36]. The percentages of mortality were transformed to arcsine square-root values for analysis of variance (ANOVA). The concentration of the test compounds required to produce $50 \%$ inhibition of $\mathrm{AChE}$ activity $\left(\mathrm{IC}_{50}\right)$ was determined using a SAS 9.13 program [37]. $\mathrm{IC}_{50}$ values and cAMP levels were subjected to ANOVA. The Bonferroni multiple-comparison method was used for comparison of means [37]. Means \pm SE of untransformed data are reported. Concentration-mortality data were subjected to probit analysis [37]. The $\mathrm{LC}_{50}$ values for each species and their treatments were considered to be significantly different from one another when their 95\% confidence limits (CLs) did not overlap.

Ethical approval was obtained from the Institutional Animal Care and Use Committees of Seoul National University for this study.

\section{Results}

\section{Chemical composition of Millettia pinnata seed} hydrodistillate

Methylation of fatty acids in MPS-HD showed that the seed hydrodistillate consists of five major fatty acids (>3.0\%) and four minor fatty acids by comparison of mass spectral data and coelution of authenticated samples following coinjection (Table 2). The five major constituents were oleic acid, linoleic acid, palmitic acid, stearic acid, and behenic acid, and comprised 38.7, 11.0, 8.5, 6.6, and $3.4 \%$ of the seed hydrodistillate, respectively.

\section{Bioassay-guided fractionation and identification}

Direct-contact mortality bioassay-guided fractionation of $M$. pinnata seed extract afforded six active principles identified by spectroscopic analyses, including MS and NMR. The six larvicidal principles were characterized as karanjin (1), karanjachromene (2), oleic acid (3), palmitic acid (4), pongamol (5), and pongarotene (6) (Figure 2) by spectroscopic analyses, including MS and NMR. Karanjin

Table 2 Chemical composition of Millettia pinnata seed hydrodistillate

\begin{tabular}{|c|c|c|c|c|c|}
\hline \multirow[t]{2}{*}{ Compound } & \multirow{2}{*}{$\begin{array}{l}\text { Lipid } \\
\text { Number }\end{array}$} & \multirow{2}{*}{$\begin{array}{l}\text { RT } \\
\text { (min) }\end{array}$} & \multirow{2}{*}{$\begin{array}{l}\% \text { area in } \\
\text { GC-FID }\end{array}$} & \multicolumn{2}{|c|}{ Identification } \\
\hline & & & & $\mathrm{Cl}$ & MS \\
\hline Palmitic acid ${ }^{*}$ & C16:0 & 10.20 & 8.5 & $\mathrm{O}$ & $\mathrm{O}$ \\
\hline Stearic acid ${ }^{*}$ & C18:0 & 11.35 & 6.6 & $\mathrm{O}$ & $\mathrm{O}$ \\
\hline Oleic acid ${ }^{*}$ & C18:1n9 & 11.52 & 38.7 & $\mathrm{O}$ & $\mathrm{O}$ \\
\hline Linoleic acid $^{*}$ & C18:2n6 & 11.85 & 11.0 & $\mathrm{O}$ & $\mathrm{O}$ \\
\hline Linolenic acid ${ }^{*}$ & C18:3n3 & 12.37 & 1.8 & $\mathrm{O}$ & $\mathrm{O}$ \\
\hline Arachidic acid ${ }^{*}$ & C20:0 & 12.97 & 1.3 & $\mathrm{O}$ & $\mathrm{O}$ \\
\hline Gadoleic acid & C20:1 & 13.20 & 0.8 & $x$ & $\mathrm{O}$ \\
\hline Behenic acid $^{*}$ & C22:0 & 15.53 & 3.4 & $\mathrm{O}$ & $\mathrm{O}$ \\
\hline Lignoceric acid & C24:0 & 19.74 & 0.8 & $x$ & $\mathrm{O}$ \\
\hline
\end{tabular}

RT, retention time; GC-FID, gas-liquid chromatography with flame ionization detection; $\mathrm{Cl}$, coinjection with authentic sample in GC-FID analysis; MS, mass spectrometry.

"Major constituent (>3\%). 
<smiles>COc1c(-c2ccccc2)oc2c(ccc3occc32)c1=O</smiles>

1<smiles>CCCCCCCC/C=C\CCCCCCCC(=O)O</smiles>

3<smiles>COc1c(C(=O)CC(=O)c2ccccc2)ccc2occc12</smiles>

5<smiles></smiles>

2<smiles>CCCCCCCCCCCCCCC(=O)O</smiles>

4<smiles>O=c1c2c(oc3c(ccc4occc43)c1=O)-c1ccccc1OC2</smiles>

Figure $\mathbf{2}$ Structures of isolated compounds. The furanoflavonoid karanjin (1), the pyranoflavonoid karanjachromene (2), the unsaturated fatty acid oleic acid (3), the saturated fatty palmitic acid (4), the dihydrochalcone flavonoid pongamol (5), and the rotenoid flavonoid pongarotene (6). These constituents are identified in Millettia pinnata seed in this study. The chemical formulae of these compounds are $\mathrm{C}_{18} \mathrm{H}_{12} \mathrm{O}_{4}(\mathbf{1}), \mathrm{C}_{21} \mathrm{H}_{18} \mathrm{O}_{4}$ (2), $\mathrm{C}_{18} \mathrm{H}_{34} \mathrm{O}_{2}(\mathbf{3}), \mathrm{C}_{18} \mathrm{H}_{32} \mathrm{O}_{2}(\mathbf{4}), \mathrm{C}_{18} \mathrm{H}_{14} \mathrm{O}_{4}(\mathbf{5})$, and $\mathrm{C}_{18} \mathrm{H}_{10} \mathrm{O}_{4}$ (6); the molar masses are 292.29, 334.36, 282.46, 256.42, 294.32, and $291.06 \mathrm{~g} / \mathrm{mol}$.

(1) was identified on the basis of the following evidence: white crystal. UV (acetone): $\lambda_{\max } \mathrm{nm}=215,340$. EI-MS (70 eV), $m / z$ (\% rel. int.): $292[\mathrm{M}]^{+}$(100), 273 (12), 263 (7), 160 (66), 149 (7), 125 (12), 97 (19), 61 (49). ${ }^{1} \mathrm{H}$ NMR $\left(\mathrm{CDCl}_{3}, 600 \mathrm{MHz}\right): \delta 3.94(3 \mathrm{H}, \mathrm{s}), 6.85,(1 \mathrm{H}, \mathrm{d} J=1.4 \mathrm{~Hz})$ $7.43(1 \mathrm{H}, \mathrm{d}, J=1.4 \mathrm{~Hz}), 7.59(3 \mathrm{H}, \mathrm{m}), 7.67(1 \mathrm{H}, \mathrm{d}, J=$ $8.8 \mathrm{~Hz}), 8.08(1 \mathrm{H}, \mathrm{d}, J=2.1 \mathrm{~Hz}), 8.11(1 \mathrm{H}, \mathrm{d}, J=8.8 \mathrm{~Hz})$, $8.21(1 \mathrm{H}, \mathrm{m})$ (Additional file 1$).{ }^{13} \mathrm{C} \mathrm{NMR}\left(\mathrm{CDCl}_{3}\right.$, $150 \mathrm{MHz}$ ): $\delta 60.3 \mathrm{q}, 105.3 \mathrm{~d}, 110.7 \mathrm{~d}, 118.2 \mathrm{~s}, 120.7 \mathrm{~s}$, $122.4 \mathrm{~d}, 127.9 \mathrm{~d}, 128.0 \mathrm{~d}, 129.3 \mathrm{~d}, 129.5 \mathrm{~d}, 130.5 \mathrm{~d}, 131.5 \mathrm{~s}$, $132.2 \mathrm{~s}, 142.6 \mathrm{~d}, 151.0 \mathrm{~s}, 155.4 \mathrm{~s}, 159.1 \mathrm{~s}, 174.9 \mathrm{~s}$ (Additional file 2). Karanjachromene (2): white crystal. UV $(\mathrm{EtOH}): \lambda_{\max } \mathrm{nm}=260,320$. EI-MS $(70 \mathrm{eV}), \mathrm{m} / z$ (\% rel. int.): 334 $[\mathrm{M}]^{+}$(64), 319 (100), 291 (21), 263 (19), 175 (33), 160 (13), 127 (5), 97 (17), 71 (21). ${ }^{1} \mathrm{H}$ NMR $\left(\mathrm{CDCl}_{3}\right.$, $600 \mathrm{MHz}): \delta 1.51(3 \mathrm{H}, \mathrm{s}), 2.05(3 \mathrm{H}, \mathrm{m}), 3.88(3 \mathrm{H}, \mathrm{s}), 5.74$ $(1 \mathrm{H}, \mathrm{d}, J=11.2 \mathrm{~Hz}), 6.85(1 \mathrm{H}, \mathrm{dd}, J=7.6$ and $10.0 \mathrm{~Hz})$, $7.55(1 \mathrm{H}, \mathrm{m}), 7.60(2 \mathrm{H}, \mathrm{m}), 7.65(1 \mathrm{H}, \mathrm{m}), 8.01(1 \mathrm{H}, \mathrm{m})$, $8.05(1 \mathrm{H}, \mathrm{d}, J=8.8 \mathrm{~Hz}), 8.10(1 \mathrm{H}, \mathrm{d}, J=6.5 \mathrm{~Hz})$ (Additional file 3). ${ }^{13} \mathrm{C}$ NMR $\left(\mathrm{CDCl}_{3}, 150 \mathrm{MHz}\right): \delta 22.5 \mathrm{q}, 22.6 \mathrm{q}, 65.0$ q, $68.4 \mathrm{~s}, 105.4 \mathrm{~s}, 109.1 \mathrm{~s}, 115.5 \mathrm{~d}, 118.0 \mathrm{~d}, 126.7 \mathrm{~d}, 127.8$ d, $128.2 \mathrm{~d}, 128.3 \mathrm{~d}, 130.2 \mathrm{~d}, 130.5 \mathrm{~d}, 130.6 \mathrm{~d}, 131.1 \mathrm{~s}$, $151.4 \mathrm{~s}, 154.7 \mathrm{~s}, 157.3 \mathrm{~s}, 157.4 \mathrm{~s}, 174.7 \mathrm{~s}$ (Additional file 4).
Oleic acid (3): white crystal. UV (EtOH): $\lambda_{\max } \mathrm{nm}=205$. EI-MS (70 eV), $m / z$ (\% rel. int.): $282[\mathrm{M}]^{+}$(3), 264 (14), 220 (3), 180 (4), 111 (21), 97 (44), 69 (76), 55 (100). ${ }^{1} \mathrm{H}$ NMR $\left(\mathrm{CDCl}_{3}, 600 \mathrm{MHz}\right): \delta 0.88(3 \mathrm{H}, \mathrm{s}), 1.29(16 \mathrm{H}, \mathrm{m})$, $1.30(2 \mathrm{H}, \mathrm{s}), 1.33(2 \mathrm{H}, \mathrm{s}), 1.64(2 \mathrm{H}, \mathrm{m}), 2.03(2 \mathrm{H}, \mathrm{m}), 2.05$ $(2 \mathrm{H}, \mathrm{m}), 2.35(2 \mathrm{H}, \mathrm{s}), 5.29(1 \mathrm{H}, \mathrm{m}), 5.34(1 \mathrm{H}, \mathrm{m}), 11.3(1 \mathrm{H}$, br) (Additional file 5). ${ }^{13} \mathrm{C}$ NMR $\left(\mathrm{CDCl}_{3}, 150 \mathrm{MHz}\right): \delta$ $14.1 \mathrm{q}, 22.7 \mathrm{t}, 24.8 \mathrm{t}, 27.3 \mathrm{t}, 29.0$ t, $29.3 \mathrm{t}, 29.4 \mathrm{t}, 29.5 \mathrm{t}$, 29.6 t, 31.9 t, 34.2 t, 130.0 d, 130.2 d, 180.6 s (Additional file 6). Palmitic acid (4): white crystal. UV (EtOH): $\lambda_{\max }$ $\mathrm{nm}=210$. EI-MS $(70 \mathrm{eV}), m / z$ (\% rel. int.): $256[\mathrm{M}]^{+}(100)$, 241 (4), 213 (20), 185 (10), 129 (32), 97 (20), 73 (58), 57 (46). ${ }^{1} \mathrm{H}$ NMR $\left(\mathrm{CDCl}_{3}, 600 \mathrm{MHz}\right): \delta 0.88(3 \mathrm{H}, \mathrm{s}), 1.29$ $(16 \mathrm{H}, \mathrm{m}), 1.30(2 \mathrm{H}, \mathrm{s}), 1.33(2 \mathrm{H}, \mathrm{s}), 1.64(2 \mathrm{H}, \mathrm{m}), 2.03(2 \mathrm{H}$, $\mathrm{m}), 2.05(2 \mathrm{H}, \mathrm{m}), 2.35(2 \mathrm{H}, \mathrm{s}), 11.6(1 \mathrm{H}, \mathrm{br})$ (Additional file 7). ${ }^{13} \mathrm{C}$ NMR $\left(\mathrm{CDCl}_{3}, 150 \mathrm{MHz}\right): \delta 14.1 \mathrm{q}, 22.7 \mathrm{t}$, 24.8 t, 27.3 t, 29.0 t, 29.3 t, 29.4 t, 29.5 t, 29.6 t, 31.9 t, 34.2 t, $179.8 \mathrm{~s}$ (Additional file 8). Pongamol (5): needle. UV (EtOH): $\lambda_{\max } \mathrm{nm}=260$, 350. EI-MS $(70 \mathrm{eV}), m / z(\%$ rel. int.): $294[\mathrm{M}]^{+}$(52), 276 (19), 263 (24), 207 (22), 179 (62), 160 (100), 148 (97), 105 (19), 75 (91). ${ }^{1} \mathrm{H}$ NMR $\left(\mathrm{CDCl}_{3}, 600 \mathrm{MHz}\right): \delta 4.25(3 \mathrm{H}, \mathrm{s}), 7.01(1 \mathrm{H}, J=8.2 \mathrm{~Hz})$, $7.15(1 \mathrm{H}, \mathrm{s}), 7.26(1 \mathrm{H}, \mathrm{d}, J=2.2 \mathrm{~Hz}), 7.36(2 \mathrm{H}, \mathrm{d}$, 
$J=0.5 \mathrm{~Hz}), 7.49(1 \mathrm{H}, \mathrm{d}, J=1.6 \mathrm{~Hz}), 7.68(2 \mathrm{H}, \mathrm{d}, J=6.5 \mathrm{~Hz})$, $7.85(1 \mathrm{H}, \mathrm{s}), 7.92(1 \mathrm{H}, \mathrm{m}), 17.20(1 \mathrm{H}, \mathrm{s})$ (Additional file 9). ${ }^{13} \mathrm{C} \mathrm{NMR}\left(\mathrm{CDCl}_{3}, 150 \mathrm{MHz}\right): \delta 61.8 \mathrm{q}, 98.3 \mathrm{~d}, 103.6 \mathrm{~d}$, 107.8 d, 108.1 s, 120.5 s, 122.5 d, 124.3 d, 126.1 d, 127.6 d, 127.6 d, 128.3 d, 130.2 s, 146.8 d, 153.0 s, 160.1 s, 185.4 s, $186.5 \mathrm{~s}$ (Additional file 10). Pongarotene (6): colorless solid. UV (EtOH): $\lambda_{\max } \mathrm{nm}=260,330$. EI-MS (70 eV), $m$ / $z$ (\% rel. int.): $290[\mathrm{M}]^{+}$(10), 205 (33), 187 (100), 176 (4), 160 (64), 145 (9), 131 (22), 121 (11), 69 (20). ${ }^{1} \mathrm{H}$ NMR $\left(\mathrm{CDCl}_{3}, 600 \mathrm{MHz}\right): \delta 6.16(2 \mathrm{H}, \mathrm{s}), 7.06(1 \mathrm{H}, \mathrm{d}, J=8.3 \mathrm{~Hz})$, $7.47(1 \mathrm{H}, \mathrm{m}), 7.67(1 \mathrm{H}, \mathrm{d}, J=3.6 \mathrm{~Hz}), 7.74(2 \mathrm{H}, \mathrm{d}, J=$ $1.7 \mathrm{~Hz}), 7.84(1 \mathrm{H}, \mathrm{dd}, J=1.7,1.8 \mathrm{~Hz}), 8.07(1 \mathrm{H}, \mathrm{dd}, J=2.2$, $14.5 \mathrm{~Hz}), 8.20(1 \mathrm{H}, \mathrm{m})$ (Additional file 11$).{ }^{13} \mathrm{C} \mathrm{NMR}$ $\left(\mathrm{CDCl}_{3}, 150 \mathrm{MHz}\right): \delta 60.4 \mathrm{t}, 103.3 \mathrm{~d}, 109.6 \mathrm{~d}, 111.6 \mathrm{~s}$, 118.5 s, 119.5 d, 121.1 s, 122.7 d, 124.9 s, 126.1 d, 127.7 d, $130.5 \mathrm{~d}, 142.4 \mathrm{~d}, 148.0 \mathrm{~s}, 149.4 \mathrm{~s}, 155.5 \mathrm{~s}, 159.0 \mathrm{~s}, 175.2 \mathrm{~s}$ (Additional file 12).

\section{Larvicidal activity of test compounds}

The toxicity of four flavonoids, eight fatty acids, four fatty acid esters, and two larvicides (temephos and fenthion) to third instar larvae from insecticide-susceptible C. pipiens pallens was evaluated by a direct-contact mortality bioassay (Table 3). Responses varied according to compound tested. Based on $24 \mathrm{~h} \mathrm{LC}_{50}$ values, karanjin $(14.61 \mathrm{mg} / \mathrm{L})$ was the most toxic compound, followed by oleic acid (18.07 mg/L) and karanjachromene (18.74 mg/L). $\mathrm{LC}_{50}$ of linoleic acid, linolenic acid, pongamol, pongarotene, elaidic acid, and palmitic acid is between 20.15 and $34.50 \mathrm{mg} /$ L. Low toxicity was produced by arachidic acid and behenic acid. Stearic acid and four fatty acid esters were ineffective. Overall, all of the constituents were less toxic than either temephos or fenthion. Mortality in the methanolsurfactant-water-treated controls for C. pipiens pallens larvae in this study was less than $2 \%$.

Toxic effects of all compounds on third instar larvae from insecticide-susceptible $A$. aegypti were likewise compared (Table 4). As judged by $24 \mathrm{~h} \mathrm{LC}_{50}$ values, karanjin $(16.13 \mathrm{mg} / \mathrm{L})$ was most toxic and was less toxic than either temephos or fenthion. $\mathrm{LC}_{50}$ of oleic acid, karanjachromene, linoleic acid, linolenic acid, and pongamol was between 18.45 and $25.76 \mathrm{mg} / \mathrm{L}$. $\mathrm{LC}_{50}$ of elaidic acid, pongarotene, and palmitic acid was between 32.16 and $42.96 \mathrm{mg} / \mathrm{L}$. Low toxicity was obtained from arachidic acid and behenic acid. Stearic acid and four fatty acid esters were ineffective.

Against third instar larvae from wild $A$. albopictus (Table 5), oleic acid (24 h $\mathrm{LC}_{50}, 18.79 \mathrm{mg} / \mathrm{L}$ ) was the most toxic compound, followed by karanjin (35.26 mg/ L). These compounds were less toxic than either temephos or fenthion. $\mathrm{LC}_{50}$ of karanjachromene, pongamol, pongarotene, elaidic acid, linoleic acid, and linolenic acid was between 52.97 and $71.34 \mathrm{mg} / \mathrm{L}$. Low toxicity was observed with palmitic acid, arachidic acid, and behenic

Table 3 Contact toxicity of four flavonoids, eight fatty acids, four fatty acid esters, and two larvicides to third instar Culex pipiens pallens larvae during a $24 \mathrm{~h}$ exposure

\begin{tabular}{|c|c|c|c|c|}
\hline Compound & $\mathrm{LC}_{50}, \mathrm{mg} / \mathrm{L}(95 \% \mathrm{CL})$ & Slope \pm SE & $x^{2 a}$ & $p$-value \\
\hline Karanjin $(1)^{b}$ & $14.61(12.11-17.81)$ & $2.2 \pm 0.30$ & 1.41 & 0.999 \\
\hline Oleic acid (3) & $18.07(15.55-20.52)$ & $3.2 \pm 0.41$ & 1.80 & 0.997 \\
\hline Karanjachromene $(2)^{\mathrm{b}}$ & $18.74(16.25-21.18)$ & $3.3 \pm 0.42$ & 1.74 & 0.997 \\
\hline Linoleic acid & 20.15 (17.13-24.44) & $2.2 \pm 0.29$ & 1.17 & 0.999 \\
\hline Linolenic acid & $21.34(18.21-25.87)$ & $2.3 \pm 0.30$ & 1.42 & 0.999 \\
\hline Pongamol $(5)^{\mathrm{b}}$ & $23.95(20.68-27.34)$ & $2.6 \pm 0.33$ & 1.26 & 0.999 \\
\hline Pongarotene $(6)^{b}$ & $25.52(22.14-29.16)$ & $2.6 \pm 0.34$ & 1.54 & 0.999 \\
\hline Elaidic acid & $28.22(25.55-31.09)$ & $3.9 \pm 0.42$ & 7.38 & 0.881 \\
\hline Palmitic acid (4) ${ }^{\mathrm{b}}$ & $34.50(36.36-40.72)$ & $3.6 \pm 0.48$ & 2.55 & 0.999 \\
\hline Arachidic acid & $54.91(50.05-60.31)$ & $3.9 \pm 0.45$ & 13.1 & 0.439 \\
\hline Behenic acid & $68.76(64.54-73.28)$ & $6.5 \pm 0.84$ & 7.42 & 0.685 \\
\hline Stearic acid & $>200$ & & & \\
\hline Methyl oleate & $>200$ & & & \\
\hline Ethyl oleate & $>200$ & & & \\
\hline Methyl linoleate & $>200$ & & & \\
\hline Ethyl linoleate & $>200$ & & & \\
\hline Temephos & $0.013(0.010-0.016)$ & $2.0 \pm 0.30$ & 2.40 & 0.935 \\
\hline Fenthion & $0.027(0.023-0.031)$ & $3.5 \pm 0.44$ & 2.81 & 0.902 \\
\hline
\end{tabular}

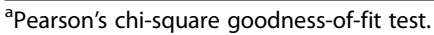

${ }^{\mathrm{b}}$ Natural compounds isolated from Millettia pinnata seed in this study. The other 10 compounds were commercially organic pure compounds. 
Table 4 Contact toxicity of four flavonoids, eight fatty acids, four fatty acid esters, and two larvicides to third instar Aedes aegypti larvae during a $24 \mathrm{~h}$ exposure

\begin{tabular}{|c|c|c|c|c|}
\hline Compound & $\mathrm{LC}_{50}, \mathrm{mg} / \mathrm{L}(95 \% \mathrm{CL})$ & Slope \pm SE & $x^{2 a}$ & $p$-value \\
\hline Karanjin $(1)^{b}$ & $16.13(13.61-18.99)$ & $2.2 \pm 0.26$ & 1.56 & 0.999 \\
\hline Oleic acid (3) & $18.45(15.75-21.08)$ & $3.0 \pm 0.40$ & 1.71 & 0.998 \\
\hline Karanjachromene $(2)^{\mathrm{b}}$ & $20.57(17.69-23.57)$ & $2.9 \pm 0.40$ & 2.02 & 0.996 \\
\hline Linoleic acid & $21.28(18.05-26.02)$ & $2.1 \pm 0.29$ & 1.24 & 0.999 \\
\hline Linolenic acid & $22.57(19.31-27.41)$ & $2.4 \pm 0.31$ & 1.01 & 0.999 \\
\hline Pongamol $(5)^{b}$ & $25.76(22.44-29.35)$ & $2.7 \pm 0.34$ & 1.48 & 0.999 \\
\hline Elaidic acid & $32.16(29.15-35.62)$ & $3.8 \pm 0.44$ & 3.13 & 0.997 \\
\hline Pongarotene $(6)^{b}$ & $37.61(33.96-41.50)$ & $3.6 \pm 0.44$ & 4.88 & 0.977 \\
\hline Palmitic acid (4) ${ }^{\mathrm{b}}$ & $42.96(39.25-46.37)$ & $4.6 \pm 0.62$ & 1.65 & 0.999 \\
\hline Arachidic acid & $60.51(55.09-67.01)$ & $3.8 \pm 0.45$ & 15.4 & 0.283 \\
\hline Behenic acid & 86.83 (81.18-92.83) & $6.1 \pm 1.20$ & 4.07 & 0.944 \\
\hline Stearic acid & $>200$ & & & \\
\hline Methyl oleate & $>200$ & & & \\
\hline Ethyl oleate & $>200$ & & & \\
\hline Methyl linoleate & $>200$ & & & \\
\hline Ethyl linoleate & $>200$ & & & \\
\hline Temephos & $0.015(0.013-0.018)$ & $2.6 \pm 0.32$ & 2.41 & 0.992 \\
\hline Fenthion & $0.022(0.019-0.024)$ & $3.6 \pm 0.43$ & 2.61 & 0.989 \\
\hline
\end{tabular}

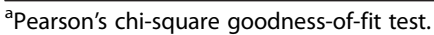

${ }^{b}$ Natural compounds isolated from Millettia pinnata seed in this study. The other 10 compounds were commercially organic pure compounds.

Table 5 Contact toxicity of four flavonoids, eight fatty acids, four fatty acid esters, and two larvicides to third instar larvae from Aedes albopictus during a $24 \mathrm{~h}$ exposure

\begin{tabular}{|c|c|c|c|c|}
\hline Compound & $\mathrm{LC}_{50}, \mathrm{mg} / \mathrm{L}(95 \% \mathrm{CL})$ & Slope \pm SE & $x^{2 a}$ & $p$-value \\
\hline Karanjin $(1)^{\mathrm{b}}$ & $35.26(31.01-39.54)$ & $3.1 \pm 0.41$ & 3.36 & 0.996 \\
\hline Oleic acid (3) ${ }^{b}$ & $18.79(16.23-21.33)$ & $3.2 \pm 0.41$ & 2.25 & 0.994 \\
\hline Karanjachromene $(2)^{\mathrm{b}}$ & $52.97(46.52-60.17)$ & $2.7 \pm 0.41$ & 5.45 & 0.963 \\
\hline Pongamol $(5)^{\mathrm{b}}$ & $56.14(49.50-64.69)$ & $2.8 \pm 0.33$ & 8.42 & 0.815 \\
\hline Pongarotene $(6)^{b}$ & $64.97(57.47-72.53)$ & $3.1 \pm 0.43$ & 3.64 & 0.994 \\
\hline Elaidic acid & $66.35(58.70-74.21)$ & $3.1 \pm 0.43$ & 3.86 & 0.992 \\
\hline Linoleic acid & $68.92(57.12-80.61)$ & $3.0 \pm 0.78$ & 1.02 & 0.996 \\
\hline Linolenic acid & 71.34 (59.95-84.19) & $2.9 \pm 0.78$ & 1.06 & 0.995 \\
\hline Palmitic acid (4) & 85.61 (78.31-93.69) & $4.5 \pm 0.63$ & 2.47 & 0.991 \\
\hline Arachidic acid & 95.01 (86.64-105.01) & $3.5 \pm 0.38$ & 6.12 & 0.986 \\
\hline Behenic acid & $105.41(98.00-113.97)$ & $4.9 \pm 0.59$ & 9.56 & 0.728 \\
\hline Stearic acid & $>200$ & & & \\
\hline Methyl oleate & $>200$ & & & \\
\hline Ethyl oleate & $>200$ & & & \\
\hline Methyl linoleate & $>200$ & & & \\
\hline Ethyl linoleate & $>200$ & & & \\
\hline Temephos & $0.010(0.009-0.011)$ & $4.1 \pm 0.46$ & 1.66 & 0.998 \\
\hline Fenthion & $0.033(0.025-0.046)$ & $1.5 \pm 0.29$ & 1.82 & 0.997 \\
\hline
\end{tabular}

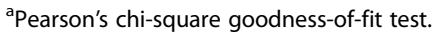

${ }^{\mathrm{b}}$ Natural compounds isolated from Millettia pinnata seed in this study. The other 10 compounds were commercially organic pure compounds. 
acid. Stearic acid and four fatty acid esters were ineffective.

\section{Acetylcholinesterase inhibition}

Because of no inhibitory effects of arachidic acid, behenic acid, and elaidic acid on $\mathrm{AChE}\left(\mathrm{IC}_{50},>50 \mathrm{mM}\right)$ in preliminary test results, the in vitro AChE inhibitory activity of four flavonoids, three unsaturated fatty acids, and one saturated fatty acid was investigated using $\mathrm{AChE}$ from $A$. aegypti larvae (Figure 3). Based on $\mathrm{IC}_{50}$ values, there were significant differences $(F=155.49$; $\mathrm{df}$ $=8,18 ; \mathrm{p}<0.0001)$ in the inhibition of AChE by the test compounds. Karanjachromene, pongarotene, pongamol, and oleic acid were the most potent $\mathrm{AChE}$ inhibitors $\left(\mathrm{IC}_{50}, 3.3-5.9 \mathrm{mM}\right)$. Linoleic acid $\left(\mathrm{IC}_{50}, 19.4 \mathrm{mM}\right)$ and linolenic acid $(21.4 \mathrm{mM})$ were significantly more pronounced at inhibiting AChE than karanjin (28.4 mM). The AChE inhibitory activity of palmitic acid was the lowest of any of the compounds examined.

\section{Effect on cyclic AMP production}

The effects of four flavonoids, four unsaturated fatty acids, and three saturated fatty acids on cAMP levels of whole body homogenates from third instar $A$. aegypti larvae were examined and compared with those induced by octopamine alone (Figure 4 ). There were significant differences $(F=1641.51 ; \mathrm{df}=12,26 ; \mathrm{p}<0.0001)$ in the cAMP levels by the test compounds. At a concentration of $100 \mu \mathrm{M}$, the cAMP levels induced by linoleic acid,

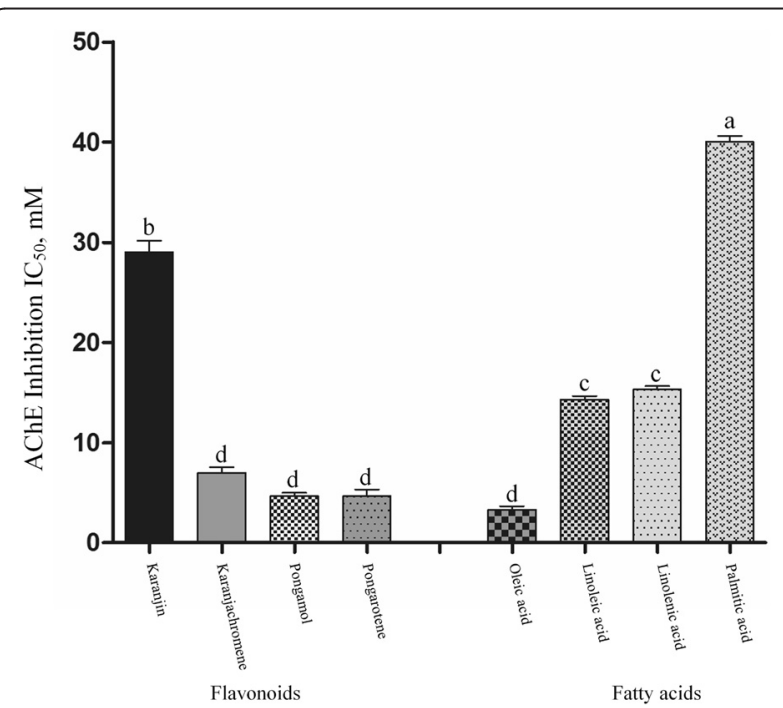

Figure $\mathbf{3}$ Inhibitory effect on acetylcholinesterase. Inhibition of acetylcholinesterase (AChE) extracted from third instar Aedes aegyptii larvae by four flavonoids, three unsaturated fatty acids, and one saturated fatty acid was measured by acetylthiocholine iodide hydrolysis at $30^{\circ} \mathrm{C}$ and $\mathrm{pH}$ 8.0. Each bar represents the mean \pm standard error of triplicate samples of three independent experiments. ( $\left(^{*} p=0.05\right.$, according to Bonferroni multiple-comparison method). linolenic acid, elaidic acid, behenic acid, and arachic acid were significantly higher than that induced by octopamine. The cAMP levels induced by the other four flavonoids and two fatty acids oleic acid and palmitic acid were significantly lower than that induced by octopamine.

\section{Efficacy of experimental liquid formulations}

The control efficacy of 12 liquid formulations significantly differed toward C. pipiens pallens ( $F=556.94 ; \mathrm{df}=6,14 ; \mathrm{p}$ $<0.0001), A$. aegypti $(F=795.42 ; \mathrm{df}=8,18 ; \mathrm{p}<0.0001)$, and A. albopictus $(F=1564.84 ; \mathrm{df}=8,18 ; \mathrm{p}<0.0001)$ (Table 6). M. pinnata seed methanol extract applied as 10\% liquid (MPS-ME-10) and seed hydrodistillate applied as $10 \%$ liquid (MPS-HD-10) provided $100 \%$ mortality toward three mosquito species larvae. The lethalities of the MPS-ME-7.5 and MPS-HD-7.5 were 100, 100 and $82 \%$ and 100,100 and $92 \%$ toward C. pipiens pallens, $A$. aegypti, and $A$. albopictus, respectively. A commercial temephos $200 \mathrm{~g} / \mathrm{L}$ treatment resulted in $100 \%$ mortality toward three mosquito species larvae.

\section{Discussion}

Certain plant preparations can be developed into products suitable for integrated vector management because they can be selective, biodegrade to nontoxic products, have few harmful effects on nontarget organisms, and are environmentally nonpersistent [16-18]. They also can be used in conjunction with biological control [18]. Sukumar et al. [16] has pointed out that the most promising botanical mosquito control agents are plants in the families Asteraceae, Cladophoraceae, Lamiaceae, Meliaceae, Oocystaceae, and Rutaceae. The efficacy of various botanical extracts and their fractions toward larvae of various mosquito species $\left(\mathrm{LC}_{50}, 2.6-44400 \mathrm{mg} / \mathrm{L}\right.$ ) has been well documented by Shaalan et al. [17], although the activity can vary significantly depending on plant species, plant tissue, age of plant, solvent used in extraction, and mosquito species [16]. In the current study, M. pinnata seed methanol extract and seed hydrodistillate exhibited good larvicidal activity against $C$. pipiens pallens, A. aegypti, and A. albopictus ( $\mathrm{LC}_{50}, 24.19-61.30 \mathrm{mg} / \mathrm{L}$ and $27.38-$ $47.99 \mathrm{mg} / \mathrm{L}$ ), although this plant belongs to the family Fabaceae. M. pinnata contains abundant flavonoid metabolites such as chromenoflavones, furanoflavones, furanoflavonols, furanochalcones, and pyranochalcones [24,25].

Many plant preparations manifest toxicity to different mosquito species larvae $[16,17,38]$ and have been proposed as potential alternatives to the conventional larvicides. Larvicidal constituents derived from plants include alkaloids (e.g., pellitorine, guineensine, pipercide, and retrofractamide $\mathrm{A}, \mathrm{LC}_{50} 0.004-0.86 \mathrm{mg} / \mathrm{L}$ [39]; piperonaline, $\mathrm{LC}_{50}$ 0.21-0.25 mg/L [40]), coumarins (e.g., imperatorin and osthole, $\mathrm{LC}_{50} 2.88$ and $3.14 \mathrm{mg} / \mathrm{L}$ [22]), phenylpropanoids (e.g., methyleugenol and $\alpha$-asarone, $\mathrm{LC}_{50} 10.49$ and 


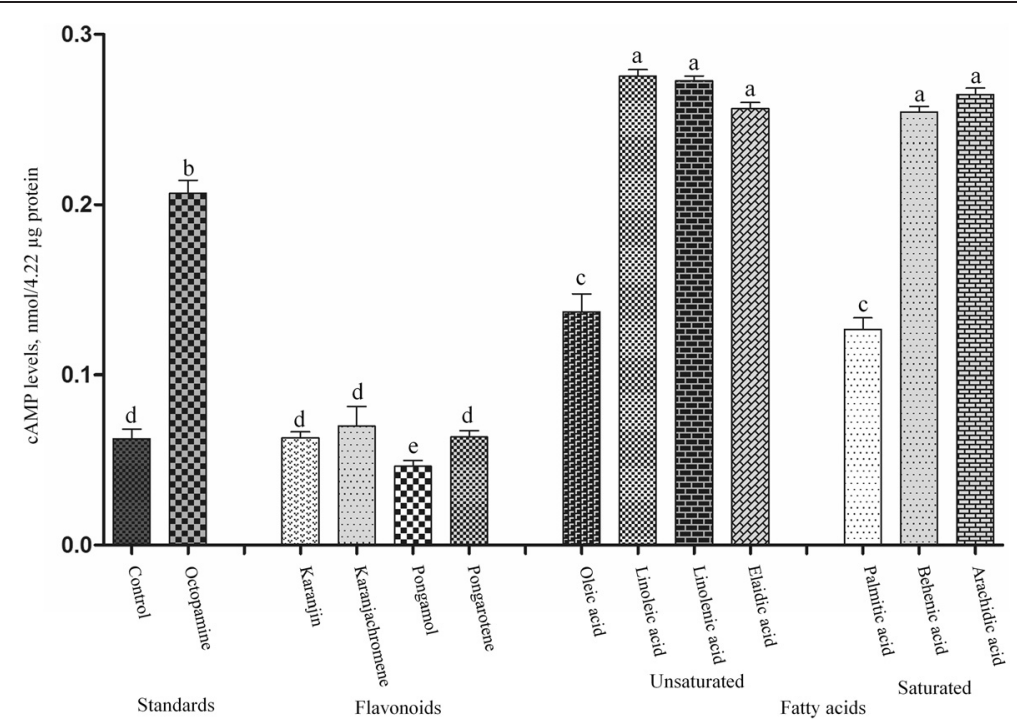

Figure 4 Effect on cyclic AMP levels. A whole body homogenate from third instar Aedes aegypti larvae was assayed for adenylate cyclase activity, as described in 'Materials and Methods' section, in the presence of $100 \mu \mathrm{M}$ of four flavonoids, four unsaturated fatty acids, and three saturated fatty acids. The effects of the test compounds on CAMP levels of the homogenate were compared with those induced by octopamine (100 $\mu M)$ alone. Data were expressed as nmol/4.22 $\mu \mathrm{g}$ protein. Each bar represents the mean \pm standard error of duplicate samples of three independent experiments. ( $* 0.05$, according to Bonferroni multiple-comparison method).

Table 6 Effectiveness of 12 experimental liquid formulations containing Millettia pinnata seed methanol extract, seed hydrodistillate, and commercial temephos emulsifiable concentrate toward larvae of three mosquito species during a $24 \mathrm{~h}$ exposure

\begin{tabular}{llll}
\hline & \multicolumn{3}{l}{ Mortality, \% ( \pm SE) } \\
\cline { 2 - 4 } Formulation (\%) & C. pipiens pallens & A. aegypti & A. albopictus \\
\hline MPS-ME-0.5 & $35 \pm 2.9 \mathrm{e}^{*}$ & $25 \pm 2.9 \mathrm{f}^{*}$ & $0 \mathrm{~g}^{*}$ \\
MPS-ME-1 & $59 \pm 2.4 \mathrm{~d}$ & $40 \pm 2.9 \mathrm{e}$ & $17 \pm 1.7 \mathrm{f}$ \\
MPS-ME-2.5 & $73 \pm 1.7 \mathrm{C}$ & $67 \pm 1.7 \mathrm{~d}$ & $37 \pm 3.3 \mathrm{e}$ \\
MPS-ME-5 & $97 \pm 1.7 \mathrm{~b}$ & $85 \pm 2.9 \mathrm{C}$ & $58 \pm 1.7 \mathrm{~d}$ \\
MPS-ME-7.5 & $100 \mathrm{a}$ & $100 \mathrm{a}$ & $82 \pm 1.7 \mathrm{C}$ \\
MPS-ME-10 & $100 \mathrm{a}$ & $100 \mathrm{a}$ & $100 \mathrm{a}$ \\
MPS-HD-0.5 & $38 \pm 1.7 \mathrm{e}$ & $26 \pm 1.7 \mathrm{f}$ & $0 \mathrm{~g}$ \\
MPS-HD-1 & $68 \pm 1.7 \mathrm{~d}$ & $45 \pm 2.9 \mathrm{e}$ & $17 \pm 1.7 \mathrm{f}$ \\
MPS-HD-2.5 & $100 \mathrm{a}$ & $68 \pm 2.9 \mathrm{~d}$ & $32 \pm 1.7 \mathrm{e}$ \\
MPS-HD-5 & $100 \mathrm{a}$ & $96 \pm 3.3 \mathrm{~b}$ & $62 \pm 2.4 \mathrm{~d}$ \\
MPS-HD-7.5 & $100 \mathrm{a}$ & $100 \mathrm{a}$ & $92 \pm 1.7 \mathrm{~b}$ \\
MPS-HD-10 & $100 \mathrm{a}$ & $100 \mathrm{a}$ & $100 \mathrm{a}$ \\
Temephos 200 g/L EC & $100 \mathrm{a}$ & $100 \mathrm{a}$ & $100 \mathrm{a}$
\end{tabular}

MPS-ME, Millettia pinnata seed methanol extract; MPS-HD, Millettia pinnata seed hydrodistillate; EC, emulsifiable concentrate.

*Means followed by the same letter in the column are not significantly different ( $p=0.05$, Bonferroni method).
$26.99 \mathrm{mg} / \mathrm{L}$ [21]; ethyl cinnamate and ethyl $p$-methoxycinnamate, $\mathrm{LC}_{50} 12.3$ and $20.7 \mathrm{mg} / \mathrm{L}$ [28]), terpenoids (e.g., 47 terpenes, $\mathrm{LC}_{50} 9.33-147.91 \mathrm{mg} / \mathrm{L}$ [41]; quassin, $\mathrm{LC}_{50} 6.0 \mathrm{mg} / \mathrm{L}$ [42]; labda-8(17)-diene-15,16-dial, $\mathrm{LC}_{50}<10 \mathrm{mg} / \mathrm{L}$ [43]), neolignans (e.g., conocarpan, eupomatenoid-5, and eupomatenoid-6, $\mathrm{LC}_{50}<10 \mathrm{mg} / \mathrm{L}$ [44]), cyanogenic glycoside (e.g., dhurrin, $\mathrm{LC}_{50} 1.12 \mathrm{mg} / \mathrm{L}$ [45]), polyacetylene (e.g., capillin, $\mathrm{LC}_{50}<10 \mathrm{mg} / \mathrm{L}$ [46]), lactones (e.g., goniothalmin, $\mathrm{LC}_{50} 0.87-25.95 \mathrm{mg} / \mathrm{L}$ [47]; butenolides 1 and 2, $\mathrm{LC}_{50} 0.41$ and $0.47 \mathrm{mg} / \mathrm{L}$ [48]), acetylenic alcohols (e.g., falcarinol and falcarindiol, $\mathrm{LC}_{50} 3.49$ and $6.51 \mathrm{mg} / \mathrm{L}$ [49]), and phenols (e.g., 4-butoxymethylphenol, $\left.\mathrm{LC}_{50} 0.05 \mathrm{mg} / \mathrm{L}[50]\right)$.

In the current study, the larvicidal principles of $M$. pinnata seed were determined to be the furanoflavonoid karanjin (1), the pyranoflavonoid karanjachromene (2), the unsaturated fatty acids oleic acid (3), the saturated fatty acids palmitic acid (4), the dihydrochalcone flavonoid pongamol (5), and the rotenoid flavonoid pongarotene (6) from seed extract, as well as the unsaturated fatty acids oleic acid, elaidic acid, linoleic acid and linolenic acid and the saturated fatty acids palmitic acid, arachidic acid and behenic acid from seed hydrodistillate. The interpretations of proton and carbon signals of compounds $1,2,3,4,5$, and 6 were largely consistent with those of Katekhaye et al. [51], Koysomboon et al. [52], Yang et al. [53], Ragona et al. [54], Parmar et al. [55], and Simin et al. [56], respectively. $\mathrm{LC}_{50}$ of the four flavonoids and the seven fatty acids was between 14.61 and $64.97 \mathrm{mg} / \mathrm{L}$ and between 18.07 and $105.41 \mathrm{mg} / \mathrm{L}$ 
toward three mosquito species larvae, respectively, although $\mathrm{LC}_{50}$ of the natural compounds stated previously is between 0.004 and $147.91 \mathrm{mg} / \mathrm{L}$. Karanjin, karanjachromene, and oleic acid were highly effective toward $C$. pipiens pallens and $A$. aegypti larvae, whereas karanjin and karanjachromene were relatively less effective toward A. albopictus larvae. Oleic acid was highly effective toward $A$. albopictus larvae. In addition, the $10 \%$ liquids containing $M$. pinnata seed methanol extract and seed hydrodistillate resulted in complete control toward three mosquito species larvae and the larvicidal activity of the liquids was comparable to that of commercial temephos $200 \mathrm{~g} / \mathrm{L}$ EC. Treatment with the 7.5\% extract and seed hydrodistillate liquids resulted in complete control toward C. pipiens pallens and A. aegypti larvae and 82 and 92\% mortality toward A. albopictus larvae, respectively. This susceptibility difference might be attributable to the development of insecticide resistance in wild A. albopictus collected near rice paddy fields and cowsheds with varying histories of insecticide use. This original finding indicates that materials derived from $M$. pinnata seed may hold promise for the development of novel and effective mosquito larvicides toward mosquito field populations. Karanjin is commercialized as an insecticide/ acaricide (20 g/L EC) for the control of mites, scales, and chewing and sucking insect pests in a wide range of agricultural crops and ornamentals [57].

QSAR analysis of phytochemicals toward mosquito larvae has been well noted $[22,39]$. However, limited information is available on larvicidal activity of fatty acids. Unsaturated fatty acids (oleic acid, linoleic acid, and linolenic acid) were reported to be more toxic than unsaturated fatty acids (myristic acid, palmitic acid, and stearic acid) toward $A$. albopictus larvae [58]. In the current study, the unsaturated fatty acids (oleic acid, linoleic acid, linolenic acid, and elaidic acid) were more pronounced in toxicity to three mosquito species larvae than the saturated fatty acids (arachidic acid, behenic acid, palmitic acid, and stearic acid). The toxicity of oleic acid, linoleic acid, and linolenic acid did not differ significantly. Oleic acid was more toxic than elaidic acid, the trans isomer of oleic acid. Palmitic acid was more toxic than arachidic acid and behenic acid. Two FAMEs methyl oleate and methyl linoleate and two fatty acid ethyl esters ethyl oleate and ethyl linoleate were ineffective. These findings indicate that it might be possible to use unsaturated fatty acids as environmentally safe and effective larvicides. QSAR indicates that structural characteristics, such as the degree of saturation, the side chain length of fatty acid, and the geometric isomerism, appear to play a role in determining the fatty acid toxicity to mosquito larvae.

Investigations on the modes of action of naturally occurring compounds may provide useful information for the development of biorational insecticides with novel target sites and for future resistance management $[17,18]$. The modes of insecticidal action of naturally occurring compounds are mainly due to AChE inhibition and interference with the octopaminergic system [18]. Certain terpenoids such as pulegone-1,2-epoxide and 1,8-cineole inhibit $\mathrm{AChE}$ from $A$. aegypti larvae $\left(\mathrm{IC}_{50}\right.$, 1.45-74.33 mM) [41], housefly and Madagascar roach [59], head louse $\left(\mathrm{IC}_{50}, 77 \mathrm{mM}\right)$ [60], and three storedproduct insect pests [61]. Ryan and Byrne [62] reported a relationship between insecticidal and electric eel $\mathrm{AChE}$ inhibitory activities of terpenoids, whereas no direct correlation between insect toxicity and $\mathrm{AChE}$ inhibition by terpenoids was also reported $[59,60]$. The octopaminergic and gamma aminobutyric acid receptors have also been suggested as novel target sites for some monoterpenoid essential oil constituents in Helicoverpa armigera (Hübner 1809 [63]) [19] and Drosophila melanogaster Meigen 1830 [64], [20], respectively.

In the current study, no correlation was found between contact toxicity and AChE inhibition. The flavonoids karanjachromene, pongamol, and pongarotene strongly inhibited mosquito larval AChE. Karanjin was 4.8-fold less pronounced at inhibiting $\mathrm{AChE}$ than karanjachromene, although the toxicity of the two flavonoids did not differ significantly. The two flavonoids had no effect on cAMP levels. These findings indicate that AChE is the main site of action of karanjin and karanjachromene. The unsaturated fatty acid oleic acid and the saturated fatty acid palmitic acid strongly and weakly inhibited AChE, respectively. The cAMP levels induced by the fatty acids were lower than that induced by octopamine alone. These findings indicate that $\mathrm{AChE}$ is the main site of action of oleic acid and palmitic acid. The unsaturated fatty acid elaidic acid and the saturated fatty acids arachidic acid and behenic acid were ineffective at inhibiting $\mathrm{AChE}$ and caused a considerable increase in cAMP levels, indicating that the mechanism of insecticidal action of elaidic acid, arachidic acid, and behenic acid might be due to interference with the octopaminergic system. Linoleic acid and linolenic acid moderately inhibited $\mathrm{AChE}$ and caused a considerable increase in cAMP levels. This finding indicates that linoleic acid and linolenic acid might act on both AChE and octopaminergic receptor. Detailed tests are needed to fully understand the exact modes of action of the flavonoids and the fatty acids. It has been also reported that karanjin suppresses ecdysteroids and, thereby, it acts as an insect growth regulator and antifeedant [57].

\section{Conclusion}

The M. pinnata seed-derived products containing the four natural flavonoids and two natural fatty acids described could be useful as larvicides in the control of 
mosquito populations. This plant is a fast-growing leguminous tree with the potential for high seed production in Indian subcontinent, south-east Asia, and humid tropical regions of the world [65]. There is, therefore, a potential source of the seed extract or hydrodistillate available as an eco-product. For practical use of the products as novel mosquito larvicides to proceed, further research is needed to establish their safety to humans, although historically, M. pinnata has been used in India and neighboring regions as a source of traditional medicines and animal fodder $[25,65,66]$. In addition, their effects on non-target aquatic organisms including larvivorous fishes and the aquatic environment need to be established. Lastly, detailed tests are needed to understand how to improve larvicidal potency and stability for eventual commercial development.

\section{Additional files}

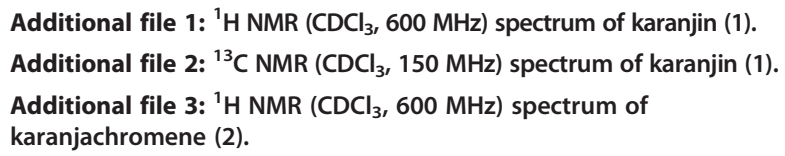

\section{Competing interests}

The authors declare that they have no competing interests.

\section{Authors' contributions}

HP and Y-JA conceived and designed the experiments. HP MJJ and J-RK performed the experiments. HP MK and Y-JA analyzed the data. HP and Y-JA wrote the paper. All authors read and approved the final manuscript.

\section{Acknowledgments}

This work was supported by Brain Korea 21 PLUS through the National Research Foundation of Korea funded by the Ministry of Education of the Korean Government to Y.-J. Ahn.

\section{Author details}

'Research Institute of Agriculture and Life Sciences, Seoul National University, Seoul 151-921, Republic of Korea. ${ }^{2}$ Department of Agricultural Biotechnology, Seoul National University, Seoul 151-921, Republic of Korea. ${ }^{3}$ National Academy of Agricultural Science, Rural Development Administration, Wanju 565-851 Jeollabuk-do, Republic of Korea. ${ }^{4}$ Department of Zoology, Bharathiar University, Coimbatore 641046Tamil Nadu, India.

Received: 4 March 2015 Accepted: 8 April 2015

Published online: 19 April 2015

\section{References}

1. Mattingly PF, Stone A, Knight KL. Culex aegypti Linnaeus, 1762 (Insecta, Diptera); proposed validation and interpretation under the plenary powers of the species so named. Z.N.(S.) 1216. Bull Zool Nomencl. 1962;19:208-19.

2. Skuse FAA. The banded mosquito of Bengal. Indian Mus Notes. 1894;3:20.

3. Coquillett DW. Report on a collection of Japanese Diptera, presented to the U. S. national museum by the Imperial University of Tokyo. Proc US Nat Mus. 1898:21:301-40.

4. Mullen G, Durden L. Medical and veterinary entomology. 2nd ed. San Diego: Academic Press; 2009

5. World Health Organization: Dengue and dengue haemorrhagic fever. Factsheet $N^{\circ} 117$. 2008. http://www.who.int/mediacentre/factsheets/fs117/ en/. Accessed 12 Dec 2014

6. Brady OJ, Gething PW, Bhatt S, Messina JP, Brownstein JS, Hoen AG, et al. Refining the global spatial limits of dengue virus transmission by evidence-based consensus. PLoS Negl Trop Dis. 2012;6(8):e1760.

7. Bhatt S, Gething PW, Brady OJ, Messina JP, Farlow AW, Moyes CL, et al. The global distribution and burden of dengue. Nature. 2013;496:504-7.

8. Centers for Disease Control and Prevention: West Nile virus-statistics \& maps. 2013. http://www.cdc.gov/westnile/statsMaps/. Accessed 08 Oct 2014.

9. Spielman A, D'Antonio M. Mosquito: the story of mankind's deadliest foe. London: Faber and Faber; 2001.

10. Halstead SB. Dengue. Lancet. 2007;370:1644-52.

11. Mota-Sanchez D, Whalon ME, Hollingworth RM, Xue Q. Documentation of pesticide resistance in arthropods. In: Whalon ME, Mota-Sanchez D, Hollingworth RM, editors. Global pesticide resistance in arthropods. Oxfordshire: CABl; 2008. p. 32-9.

12. Environmental Protection Agency: Pesticides reregistration performance measures and goals. 2011. https://www.federalregister.gov/articles/2011/03/ 02/2011-4649/pesticide-reregistration-performance-measures-and-goals. Accessed 08 Oct 2014.

13. European Union. Commission Regulation (EC) No. 1048/2005 of 13 June 2005 amending Regulation (EC) No. 2032/2003 on the second phase of the 10-year work programme referred to in Article 16(2) of Directive 98/8/EC of the European Parliament and of the Council concerning the placing of biocidal products on the market. Off J Eur Union. 9.7.2005.

14. Richie TL, Saul A. Progress and challenges for malaria vaccines. Nature. 2002;415:694-701.

15. Zorlu S, Fleck F. Dengue vaccine roll-out: getting ahead of the game. Bull World Health Org. 2011;89:476-7.

16. Sukumar K, Perich MJ, Boobar LR. Botanical derivatives in mosquito control: a review. J Am Mosq Control Assoc. 1991;7:210-37.

17. Shaalan E, Canyon D, Younes MWF, Abdel-Wahab H, Mansour A. A review of botanical phytochemicals with mosquitocidal potential. Environ Int. 2005;31:1149-66

18. Isman MB. Botanical insecticides, deterrents, and repellents in modern agriculture and an increasingly regulated world. Annu Rev Entomol. 2006;51:45-66.

19. Kostyukovsky M, Rafaeli A, Gileadi C, Demchenko N, Shaaya E. Activation of octopaminergic receptors by essential oil constituents isolated from aromatic plants: possible mode of action against insect pests. Pest Manag Sci. 2002;58:1101-6.

20. Priestley CM, Williamson EM, Wafford KA, Sattelle DB. Thymol, a constituent of thyme essential oil, is a positive allosteric modulator of human GABA receptors and a homo-oligomeric GABA receptor from Drosophila melanogaster. Br J Pharmacol. 2003;140:1363-72.

21. Perumalsamy $\mathrm{H}$, Chang KS, Park C, Ahn YJ. Larvicidal activity of Asarum heterotropoides root constituents against insecticide-susceptible and -resistant Culex pipiens pallens and Aedes aegypti and Ochlerotatus togoi. J Agric Food Chem. 2010;58:10001-6.

22. Wang Z, Kim JR, Wang M, Shu S, Ahn YJ. Larvicidal activity of Cnidium monnieri fruit coumarins and structurally related compounds against insecticide-susceptible and insecticide-resistant Culex pipiens pallens and Aedes aegypti. Pest Manag Sci. 2012;68:1041-7.

23. Isman MB. Botanical insecticides: for richer, for poorer. Pest Manag Sci. 2008;64:8-11.

24. Arote SR, Yeole PG. Pongamia pinnata: a comprehensive review. Int J Pharm Tech Res. 2010;2:2283-90.

25. Meera B, Kumar S, Kalidhar SB. A review of the chemistry and biological activity of Pongamia pinnata. J Med Aromatic Plant Sci. $2003 ; 25: 441-65$ 
26. Opong-Mensa K. A review of temephos with particular reference to West Africa onchocerciasis control program. Residue Rev. 1984;91:47-69.

27. Yang YC, Park IK, Kim EH, Lee HS, Ahn YJ. Larvicidal activity of medicinal plant extracts against Aedes aegypti, Aedes togoi, and Culex pipiens pallens (Diptera: Culicidae). J Asia Pac Entomol. 2004;7:227-32.

28. Kim NJ, Byun SG, Cho JE, Chung K, Ahn YJ. Larvicidal activity of Kaempferia galanga rhizome phenylpropanoids towards three mosquito species. Pest Manag Sci. 2008;64:857-62.

29. Pavithra HR, Gowda B, Kumar KR, Prasanna KT, Shivanna MB. Oil, fatty acid profile and karanjin content in developing Pongamia pinnata (L.) Pierre seeds. J Am Oil Chem Soc. 2012;89:2237-44.

30. Khamchum C, Punsuvon V, Kasemsumran S, Suttiwijitpukdee N. A feasibility study of oil content and fatty acid composition of seed powder and seed oil of Pongamia pinnata by near infrared spectroscopy. Sci Asia. 2013;39:384-91.

31. Rafael G, Mancha M. One-step lipid extraction and fatty acid methyl esters preparation from fresh plant tissues. Anal Biochem. 1993;211:139-43.

32. Bradford MM. A rapid and sensitive for the quantitation of microgram quantities of protein utilizing the principle of protein-dye binding. Anal Biochem. 1976;72:248-54

33. Hemingway J. Techniques to detect insecticide resistance mechanisms (field and laboratory manual). Document WHO/CDC/CPC/MAL/98.6. Geneva: World Health Organization; 1998.

34. Ellman GL, Courtney KD, Andres V, Feather-Stone RM. A new and rapid colorimetric determination of acetylcholinesterase activity. Biochem Pharmacol. 1961;7:88-95.

35. Pratt S, Pryor SC. Dopamine- and octopamine-sensitive adenylate cyclase in the brain of adult Culex pipiens mosquitoes. Cell Mol Neurobiol. 1986:6:325-9.

36. Abbott WS. A method of computing the effectiveness of an insecticide. Econ Entomol. 1925:18:265-7.

37. Institute SAS. SAS 9.13 program, 2nd ed. Cary: SAS Institute; 2014.

38. Kishore N, Mishra BB, Tiwari VK, Tripathi V. A review on natural products with mosquitosidal potentials. In: Tiwari VK, Mishra BB, editors. Opportunity, challenge and scope of natural products in medicinal chemistry. Kerala: Research Signpost; 2011. p. 335-65.

39. Park IK, Lee SG, Shin SC, Park JD, Ahn YJ. Larvicidal activity of isobutylamides identified in Piper nigrum fruits against three mosquito species. J Agric Food Chem. 2002;50:1866-70.

40. Lee SE. Mosquito larvicidal activity of pipernonaline, a piperidine alkaloid derived from long pepper, Piper longum. J Am Mosq Control Assoc. 2000;16:245-7.

41. Lee DC, Ahn YJ. Laboratory and simulated field bioassays to evaluate larvicidal activity of Pinus densiflora hydrodistillate, its constituents and structurally related compounds against Aedes albopictus, Aedes aegypti and Culex pipiens pallens in relation to their inhibitory effects on acetylcholinesterase activity. Insects. 2013;4:217-29.

42. Evans DA, Raj RK. Larvicidal efficacy of quassin against Culex quinquefasciatus. Indian J Med Res. 1991:93:324-7.

43. Roth GN, Chandra A, Nair MG. Novel bioactivities of Curcuma longa constituents. J Nat Prod. 1998:61:542-5.

44. Chauret DC, Bernard CB, Arnason JT, Durst T, Krishnamurty HG, SanchezVindas $P$, et al. Insecticidal neolignans from Piper decurrens. J Nat Prod. 1996;59:152-5.

45. Jackson FL, Behkeit SS, eL Etr SM, Quach NK. Larvicidal effects of grain sorghum (Sorghum bicolour) seedling extracts upon Culex pipiens larvae. J Am Mosq Control Assoc. 1990;6:500-3.

46. Banerji A, Luthria DL, Kokate SD. Toxicity of capillin, the insecticidal principle of Artemisia nilagirica Clarke. Indian J Exp Biol. 1990;28:588-9.

47. Kabir KE, Khan AR, Mosaddik MA. Goniothalamin - a potent mosquito larvicide from Bryonopsis laciniosa L. J Appl Entomol. 2003;127:112-5.

48. Ratnayake R, Karunaratne V, Ratnayake Bandara BM, Kumar V, MacLeod JK, Simmonds $P$, et al. Two new lactones with mosquito larvicidal activity from three Hortonia species. J Nat Prod. 2001;64:376-8.

49. Eckenbach U, Lampman RL, Seigler DS, Ebinger J, Novak RJ. Mosquitocidal activity of acetylenic compounds from Cryptotaenia canadensis. J Chem Ecol. 1999:25:1885-93.

50. Sun R, Sacalis JN, Chin C, Still CC. Bioactive aromatic compounds from leaves and stems of Vanilla fragrans. J Agric Food Chem. 2001;49:5161-4.
51. Katekhaye SD, Kale MS, Laddha KS. A simple and improved method for isolation of karanjin from Pongamia pinnata Linn. seed oil. Indian J Nat Prod Res. 2012;3:131-4.

52. Koysomboon S, van Altena I, Kato S, Chantrapromma K. Antimycobacteria flavonoids from Derris indica. Phytochemistry. 2006;67:1034-40.

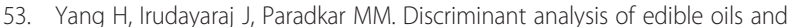
fats by FTIR, FT-NIR and FT-Raman spectroscopy. Food Chem. 2005;93:25-32.

54. Ragona L, Fogolari F, Zetta L, Pérez DM, Puyol P, De Kruif K, et al. Bovine beta-lactoglobulin: interaction studies with palmitic acid. Protein Sci. 2000;9:1347-56.

55. Parmar VS, Rathore JS, Jain R, Hrnderson DA, Malone JF. Occurrence of pongamol as the enol structure in Tephrosia purpurea. Phytochemistry. 1989:28:591-3.

56. Simin K, Ali Z, Khaliq-Uz-Zaman SM, Ahmad VU. Structure and biological activity of a new rotenoid from Pongamia pinnata. Nat Prod Lett. 2002;16:351-7.

57. Copping LG, Duke SO. Natural products that have been used commercially as crop protection agents. Pest Manag Sci. 2007;63:524-54.

58. Harada K, Suomalainen M, Uchida H, Masui H, Ohmura K, Kiviranta J, et al. Insecticidal compounds against mosquito larvae from Oscillatoria agardhii strain 27. Environ Toxicol. 2000;15:114-9.

59. Grundy DL, Still CC. Inhibition of acetylcholinesterase by pulegone-1,2-epoxide. Pestic Biochem Physiol. 1985;23:383-8.

60. Picollo MI, Toloza AC, Mougabure G, Zygadlo J, Zerba E. Anticholinesterase and pediculicidal activities of monoterpenoids. Fitoterapia. 2008;79:271-8.

61. López MD, Pascual-Villalobos MJ. Mode of inhibition of acetylcholinesterase by monoterpenoids and implications for pest control. Ind Crop Prod. 2010;31:284-8.

62. Ryan MF, Byrne O. Plant-insect coevolution and inhibition of acetylcholinesterase. J Chem Ecol. 1988:14:1965-75.

63. Hardwick DF. The corn earworm complex. Mem Entomol Soc Can 1965;97:5-247.

64. Meigen JW. Systematische Beschreibung der bekannten europäischen zweiflugeligen Insekten, 6 Theil. Schulzische Buchhandlung, Hamm. 1830

65. Scott PT, Pregelj L, Chen N, Hadler JS, Djordjevic MA, Gresshoff PM. Pongamia pinnata: an untapped resource for the biofuels industry of the future. Bioenerg Res. 2008:1:2-11.

66. Kirtikar KR, Basu BD. Indian medicinal plants. 2nd ed. International Book Distributors: Dehradun: 1995.

\section{Submit your next manuscript to BioMed Central and take full advantage of:}

- Convenient online submission

- Thorough peer review

- No space constraints or color figure charges

- Immediate publication on acceptance

- Inclusion in PubMed, CAS, Scopus and Google Scholar

- Research which is freely available for redistribution 